\title{
PERAN LEMBAGA KEUANGAN MIKRO AGRIBISNIS (LKM- A) AMANAH MANDIRI SYARI'AH TERHADAP KELOMPOK TANI \\ DI DESA SEKARPUTIH KECAMATAN BAGOR KABUPATEN NGANJUK
}

\author{
Oleh \\ Mukhamad Zakariya \\ Institut Agama Islam Pangeran Diponegoro Nganjuk \\ mukhamadzakaria@iaipd-nganjuk.ac.id
}

\begin{abstract}
We know that financial institutions are not only in the financial sector but there are also financial institutions engaged in the agricultural sector or called Agribusiness. The financial manager of this institution has been legalized by the government as the Agribusiness Microfinance Institution (LKMA). Researchers are interested in raising this theme by making LKMA Amanah Mandiri Syariah in Sekarputih Village, Bagor District, Nganjuk Regency as an object. Considering the large number of LKMA at the village level but the agricultural process seems to be still lacking. Moreover, one of the factors is the minimal capital of farmers. Supposedly with the LKMA the farmers can easily provide capital to improve agricultural products that directly impact the welfare of the surrounding community. Data collection was conducted through interviews using observation and interview guidelines. Data analysis used is descriptive statistics. The results show that the Agribusiness Microfinance Institution (LKMA) plays a role in improving the progress of farmer group members and contributes to increasing the participation of farmers in the group and contributing to increasing the amount of farm yields, land ownership and acceptance for farmers.
\end{abstract}

Keywords: Agribusiness Microfinance Institution, Sharia Economy, Farmers Group 


\begin{abstract}
Abstrak
Kita ketahui lembaga keuangan ternyata bukan pada sektor finansial saja tetapi ada juga lembaga keuangan yang bergerak dalam sektor pertanian atau disebut dengan Agribisnis. Pengelola keuangan secara lembaga ini sudah dilegalkan oleh pemerintah dengan nama Lembaga Keuangan Mikro Agribisnis (LKMA). Peneliti tertarik mengangkat tema ini dengan menjadikan LKMA Amanah Mandiri Syariah di Desa Sekarputih Kecamatan Bagor Kabupaten Nganjuk sebagai objek. Mengingat banyaknya LKMA di tingkat Desa tetapi proses pertanian sepertinya masih kurang maksimal. Apalagi salah satu faktornya adalah modal petani yang sangat minim. Semestinya dengan adanya LKMA para petani bisa dengan mudah memberikan modal untuk meningkatkan hasil pertanian yang secara langsung berimbas pada kesejahteraan masyarakat sekitar. Pengumpulan data dilakukan melalui wawancara dengan menggunakan pedoman observasi dan wawancara. Analisis data yang digunakan adalah statistik deskriptif. Hasil penelitian menunjukkan bahwa Lembaga Keuangan Mikro Agribisnis (LKMA) berperan dalam meningkatkan kemajuan anggota kelompok tani dan ikut meningkatkan partisipasi petani dalam kelompok serta berperan dalam meningkatkan jumlah hasil panen tani, kepemilikan lahan dan penerimaan bagi petani.
\end{abstract}

Kata Kunci: Lembaga Keuangan Mikro Agribisnis, Ekonomi Syariah, Kelompok Tani

\title{
Pendahuluan
}

Pengembangan sektor pertanian sampai saat ini telah banyak di lakukan di Indonesia. Selain sebagai salah satu upaya dalam meningkatkan pendapatan petani, sektor pertanian juga merupakan salah satu penggerak pembangunan nasional. Namun yang saat ini terjadi di Indonesia adalah munculnya masalah- masalah pertanian seperti masalah kondisi petani, lemahnya organisasi petani dan masalah permodalan. Sebab utama kelangkaan modal adalah kecilnya tabungan atau kurangnya investasi didalam produksi yang mampu menaikkan tingkat pertumbuhan ekonomi. Karena pendapatan perkapita rendah, penduduk tidak dapat menabung banyak, sehingga bagian yang tersisa untuk investasi lebih lanjut hanya sedikit. Hal ini 
mengakibatkan produktivitas masyarakat dalam berusaha menurun dan kurang maksimalnya dalam memproduksi hasil tani.

Modal merupakan masalah utama yang selalu muncul dalam upaya pengembangan potensi dan kemampuan masyarakat, terutama di wilayah pedesaan. Upaya peningkatan pendapatan masyarakat baik melalui penggunaan inovasi selalu terkendala oleh kelangkaan modal. Telah banyak bantuan yang diberikan oleh pemerintah dan telah banyak sistem yang dikembangkan untuk penguatan modal masyarakat, tetapi selalu kandas ditengah jalan. Mulai dari KUT (Kredit Usaha Tani), Bantuan Langsung Masyarakat (BLM), Bantuan Pinjaman Langsung Masyarakat (BPLM), dan lain sebagainya. Begitu pula dengan pola bantuan kemitraan, bantuan bapak angkat dan lainnya belum banyak yang mampu meningkatkan pendapatan masyarakat dan belum banyak yang berhasil memicu pertumbuhan ekonomi masyarakat, apalagi untuk menciptakan dan menguatkan kemandirian masyarakat. ${ }^{2}$

Sejalan dengan format penumbuhan kelembagaan tani di pedesaan, Menteri Pertanian melalui Peraturan Menteri Pertanian Nomor 273/Kpts/OT. 160/4/2007 telah menetapkan Gapoktan merupakan format final dari organisasi ditingkat petani dipedesaan yang didalamnya terkandung fungsi-fungsi pengelola antara lain unit pengelola dan hasil, unit penyediaan saprodi dan unit kelembagaan keuangan mikro. Melalui Permentan 273 Kementerian Pertanian telah menetapkan dan mewadahi gapoktan sebagai kelembagaan ekonomi petani serta menentukan arah pembinaan petani dipedesaan. Gapoktan yang memperoleh Bantuan Langsung Masyarakat (BLM) PUAP, diarahkan untuk dibina dan ditumbuhkan menjadi Lembaga Keuangan Mikro Agribisnis (LKM-A) sebagai salah satu unit usaha Gapoktan. ${ }^{4}$

Penumbuhan LKM-A pada Gapoktan merupakan langkah strategis untuk menyelesaikan persoalan pembiayaan petani mikro dan buruh tani yang selama ini sulit mendapat pelayanan keuangan melalui lembaga keuangan formal. Sebagai langkah pemberdayaan LKM-A dimaksudkan untuk: (1) memberikan kepastian pelayanan dan kemudahan akses petani pada fasilitas pembiayaan, (2) prosedur 
yang sederhana dan cepat, (3) kedekatan lokasi pelayanan dengan tempat usaha tani, (4) pengelola LKM-A sangat memahami karakter petani sebagai nasabah. ${ }^{5}$

Pengembangan Lembaga Keuangan Mikro (LKM) dilingkungan Gapoktan mempunyai nilai strategis diantaranya adalah: (1) penanggulangan kemiskinan harus dilakukan dengan cara berkelanjutan, (2) proporsi terbesar orang miskin $(92,7 \%$ ) adalah pengusaha mikro; (3) kebutuhan terbesar pengusaha mikro adalah akses pada pelayanan keuangan; (4) Bank tidak mungkin mampu langsung mencapai usaha mikro kecuali melalui Lembaga Keuangan Mikro (LKM); (5) di Indonesia, keuangan mikro sudah mempunyai sejarah panjang; (6) rakyat seharusnya memiliki potensi untuk mengembangkan lembaga keuangan mikro (potensi simpan dan pembiayaan $)^{6}$.

Berdasarkan pada hal-hal diatas, maka penelitian ini penting untuk dilaksanakan, agar dapat digambarkan fungsi dan kerja yang dilakukan LKM- A "Amanah Mandiri" melalui pengelolaan keuangannya dan juga setelah diketahui kondisi pengelolaan keuangan tersebut maka LKM-A “Amanah Mandiri” bisa mengambil kebijakan untuk pengembangan LKM-A kedepannya dalam penyaluran dan pengumpulan dana sehingga hal ini akan membantu dalam menjangkau anggota yang sulit memperoleh akses terhadap permodalan.

Desa Sekarputih, merupakan desa penghasil tanaman pangan Padi, Jagung dan kedelai. Produksi padi dan jagung terus meningkat dari tahun ke tahun. Hal ini disebabkan oleh pengembangan dan ketekunan para petani dalam pengolahan lahan dan dijadikan sebagai komoditas unggulan di wilayah desa Sekarputih. Pengembangan produksi tanaman pangan secara kuantitas dan kualitas diharapkan dapat memperbaiki pangsa pasar pangan. Maka keberadaan kredit dalam LKM-A bagi masyarakat diharapkan mampu menjadi ujung tombak dalam pembiayaan sektor usaha tani yang berskala kecil. Sehingga peran LKM-A sebagai penyalur modal yang mudah oleh masyarakat dan diharapkan mampu menumbuh kembangkan sektor pertanian, khususnya padi, jagung dan kedelai. 


\section{Metode Penelitian}

Penelitian ini peneliti menggunakan pendekatan diskriptif. Pada umumnya penelitian diskriptif tidak menggunakan hipotesis (non hipotesis) sehingga dalam penelitiannya tidak perlu merumuskan hipotesis. Sedangkan jenis penelitian ini yang digunakan adalah studi kasus yaitu penelitian yang digunakan secara intensif, terinci, dan mendalam terhadap suatu organisasi, lembaga atau gejala-gejala tertentu.

Penelitian ini fokus di Lembaga Keuangan Mikro Agribisnis Amanah Mandiri Syariah dan Kelompok Tani di Desa Sekarputih Kecamatan Bagor Kabupaten Nganjuk, dengan fokus penelitian pada tingkat kemajuan kelompok tani. Peneliti memilih lokasi LKMA Amanah Mandiri Syariah Desa Sekarputih Kecamatan Bagor Kabupaten Nganjuk, karena lembaga ini adalah lembaga satu-satunya yang ada di Kabupaten Nganjuk yang merupakan unit usaha dari gabungan kelompok tani dan juga termasuk lembaga penerima PUAP yang berjalan sampai dengan sekarang bisa memenuhi permintaan kebutuhan modal petani untuk biaya masa tanam sampai panen.

Sumber data adalah tempat peneliti mengamati, membaca atau bertanya tentang data. ${ }^{39}$ Sumber data melibatkan dalam penelitian ini adalah data kualitatif dan data kuantitatif. Data kualitatif berupa deskripsi atas peran LKMA Amanah Mandiri Syariah terhadap kelompok tani, cara meningkatkan modal kelompok tani, tingkat kemajuan kelompok tani setelah adanya LKMA Amanah Mandiri Syariah. Sedang data kualitatif adalah tingkat kehadiran petani dalam kegiatan pemberdayaan dan perkembangan hasil petani saat panen.

Pengumpulan data untuk penelitian kualitatif ini adalah. Pertama, penelitian dilakukan lebih dari satu kali. Kedua, dalam melakukan pengumpulan data selalu disesuaikan dengan situasi alamiah. Ketiga, lakukan probing terhadap symbol. Probing adalah proses eksplorasi lebih dalam terhadap suatu hal yang di rasa perlu untuk di ungkap.

Berikut prosedur pengumpulan data melalui 1) Wawancara, merupakan alat re-cheking atau pembuktian terhadap informasi atau keterangan yang diperoleh sebelumnya. Wawancara yang digunakan 
ada dua model yaitu wawncara terstruktur dan tidak Terstruktur. 2) Observasi, alasan peneliti melakukan observasi adalah untuk menjawab pertanyaan, untuk membantu mengerti perilaku manusia, dan untuk evaluasi yaitu melakukan pengukuran terhadap aspek tertentu melakukan umpan balik terhadap pengukuran tersebut. 3) Studi Dokumentasi yaitu salah satu metode pengumpulan data kualitatif dengan melihat atau menganalisis dokumen-dokumen yang dibuat oleh subjek sendiri atau oleh orang lain tentang subjek.

Proses analisis data ini dengan seluruh data yang tersedia dari berbagai sumber yaitu observasi, wawancara dan dokumentasi yang pernah ditulis dalam catatan lapangan, yang selanjutnya diklarifikasikan sesuai dengan dekripsi kualitatif yang menggambarkan kondisi latar penelitian dalam sebuah penelitian sebab dalam tahap ini semua hasil penelitian yang diperoleh dilapangan dituangkan sekaligus pengukuran pendapat, rumusanrumusan atau hukum-hukum teoritik yang dibangun.

Analisis data penelitian bersifat interaktif (berkelanjutan) dan dikembangkan secara program. Analisis data dilaksanakan mulai penetapan masalah penelitian, peneliti sudah melakukan analisis terhadap permaslahan tersebut dalam berbagai perspektif teori dan metode yang di gunakan menurut Miles dan Huberman, juga yi, tahap analisis data dalam penelitian kualitatif secara umum dimulai sejak pengumpulan data, reduksi data yang diperoleh dari lapangan akan dibentuk dalam uraian yang lengkap. Penyajian data (display data), dan penarikan kesimpulan serta verifikasi yaitu difokuskan secara sistematik.

Proses analisis data dimulai dengan menelaah selluruh data yang tersedia dari berbagai sumber yaitu, Dario wawancara, pengamatan, dokumen-dokumen, gambar, foto, sebagainya, data-data, tersebut ditelaah dan dipilih kemudian dilakukan dengan pengelompokan atas data yang sejenis dan selanjutnya dianalisis sesuai dengan informasi yang dibutuhkan dengan kongkrit dan memadai, selanjutnya dengan langkah reduksi data, yang dilakukan dengan jalan melakukan abstraksi, abstraksi adalah usaha membuat 
rangkuman inti dan setelah itu dilakukan dengan mengadakan tehnik keabsahan data.

\section{Hasil Dan Pembahasan}

\section{Peran LKMA Amanah Mandiri Syariah Terhadap Kelompok Tani}

Mengenai peran LKMA Amanah Mandiri Syariah terhadap kelompok tani, memberikan pinjaman modal usaha kepada anggota LKMA untuk membeli kebutuhan pertanian seperti benih, pupuk dan lain-lain dengan menggunakan akad pembiayaan Musyarakah dimana anggota sebagai pemilik ladang pertanian sekaligus sebagai penggarap kemudian LKMA penyedia modal untuk memenuhi kebutuhanya. Dengan memberikan pembiayaan pihak LKMA tidak turun langsung untuk memenuhi kebutuhan pertanian melainkan melimpahkan wakil kepada anggota pembiayaan usaha pertanian.

Tugas pokok lembaga keuangan syariah pada umumnya memberikan fasilitas atau intermediary dengan mengumpulkan dana dari masyarakat dan memberikan pembiayaan dana untuk memenuhi kebutuhan pihak-pihak yang memerlukan, maka sistem pembiayaan pada lembaga keuangan syariah suatu kerangka dari prosedurprosedur yang berhubungan dengan proses penyedian uang berdasarkan kesepakatan atau persetujuan dari kedua belah pihak. Selain itu, sebagai lembaga keuangan yang dipercaya oleh masyarakat untuk mengelola uang yang ditabung, lkma tidak bisa berlaku spikulasi dalam menyalurkan dana simpanan anggota pada pembiayaan. Ada beberapa perjanjian diawal sebelum berlanjut ke langkah selanjutnya. Perjanjian ini berfungsi sebagai dasar hukum bagi kedua belah pihak, memperjelas hak dan kewajiban kedua belah pihak serta sebagai dasar lahirnya perjanjian asuransi.

Untuk mendapatkan pembiayaan, calon debitur harus memenuhi persyaratan yang diajukan pihak lembaga yang dalam hal ini bertindak sebagai kreditur. LKMA Amanah Mandiri Syariah dalam menentukan persyaratan untuk menjadi debitur tergantung dari jenis usahanya dan skim pembiayaan yang dibutuhkan calon debitur. Dalam memberikan pembiayaan, kreditur mempunyai suatu persyaratan yang 
standart atau baku, persyaratan untuk menjadi debitur biasanya disesuaikan dengan jenis usaha dan skim pembiayaan yang diberikan, karena setiap jenis pembiayaan dibedakan pula persyaratanya.

Dalam prakteknya isi perjanjian pembiayaan antara suatu lembaga keuangan dengan lembaga keuangan lainya berbeda, hal ini terjadi dalam rangka untuk menyesuaikan diri dengan kebutuhannya masing-masing. Hal ini juga berlaku pada LKMA Amanah mandiri Syariah, tetapi pada dasarnya suatu perjanjian dibuat dalam bentuk tertulis.

Sebelum perjanjian ditanda tangani kedua belah pihak, calon debitur harus melalui beberapa tahap yang meliputi: Petama, calon debitur wajib mengisi form permohonan pembiayaan yang sudah disediakan oleh lembaga, kemudian diajukan kepada pihak lembaga. Kedua, jika form permohonan pembiayaan telah diterima lembaga, lembaga melakukan pemeriksaan yaitu dengan melihat apakah pembiayaan yang diajukan, masuk dalam pasar sasaran dan KRD (Kriteria Resiko yang dapat Dilayani) serta apakah telah memenuhi kelengkapan administrasi yang dibutuhkan untuk mengajukan permohonan pembiayaan (seperti: menyerahkan fotokopi KTP/SIM/Identitaas lainya ditambah menyerahkan legalitas lainya). Apabila form permohonan pembiayaan yang diajukan masuk kategori diatas, maka lembaga akan melakukan penelitian dan analisis dengan cara melakukan kunjungan atau melihat secara langsung kegiatan usaha yang dijalankan calon debitur, kemudian lembaga melakukan wawancara dengan calon debitur. Calon debitur juga harus memenuhi kriteria 5C (Character/penilaian terhadap kepribadian, Capital/modal, Capacity/kemampuan, Condition of Economy/kondisi ekonomi, dan Collateral/agunan).

Ketiga, bila penelitian dan analisis telah dilakukan oleh pihak lembaga, kemudian dilakukan pemutusan pembiayaan oleh pejabat pembiayaan. Lembaga kemudian mengeluarkan surat penawaran putusan pembiayaan (SP3) yang berisi tentang persyaratan pembiayaan yaitu meliputi jumlah pembiayaan, jangka waktu pembiayaan dan lain-lain, surat ini kemudian diajukan kepada calon debitur, apabila calon debitur menyetujui maka dibuat dibuat 
perjanjian sesuai dengan persyaratan pembiayaan yang telah disepakati.72

Perjanjian pembiayaan yang biasanya digunakan dalam bentuk dibawah tangan. Dalam praktek bentuk perjanjian ini dinamakan perjanjian standar atau baku. Maksudnya adalah bahwa perjanjian yang isinya sudah dibakukan oleh atau sudah dalam bentuk tertulis dan dibuat oleh pihak yang kuat yaitu pihak kreditur (bank/lembaga keuangan).

Bank atau lembaga keuangan dalam memberikan pembiayaan harus melakukan proteksi terhadap pembiayaanya, maka agunan yang berupa aktiva tetap atau benda tidak bergerak dan benda bergerak tersebut diasuransikan. Tetapi di LKMA Amanah Mandiri karena sifatnya pengelolaan kelompok tani yang ada di Desa Sekarputih untuk proteksi terhadap pembiayaan bersifat kekeluargaan dengan saling percaya antara LKMA dengan kelompok tani atau anggotanya.

Dalam praktek di LKMA Amanah Mandiri Syariah ini tidak seperti halnya di lembaga keuangan lainya seperti Bank atau Koperasi lainya karena lembaga ini bersifat mikro yang segi pelayanannya di fokuskan pada masyarakat desa Sekarputih khususnya pada kelompok tani sehingga persyaratan atau proses dalam pemberian modal pembiayaan tidak lama.

\section{Meningkatkan Besaran Modal Kelompok Tani}

Mengenai cara meningkatkan modal kelompok tani di Desa Sekarputih, kami mewawancarai Imam Sutardji, yang mengatakan bahwa Langkah pertama meningkatkan modal adalah dengan melalui pengajuan pembiayaan ke LKMA Amanah Mandiri Syariah untuk digunakan dalam kebutuhan seperti pembelian benih, pupuk, obatobatan dan biaya operasional seperti biaya traktor, penggalengan, dan masa tanam, dan mengikuti pelatihan-pelatihan yang di adakan dinas pertanian maupun desa untuk peningkatan kapasitas petani.

Dari hasil wawancara yang penulis lakukan bahwa pembiayaan di LKMA Amanah Mandiri Syariah dana yang disalurkan langsung kepada kelompok merupakan penguatan modal untuk terus dipupuk dan selanjutnya digulirkan guna memperluas sasaran 
penerima manfaat. Dana penguatan modal dapat digulirkan dengan pola perguliran yang bersifat spesifik lokal yang bervariasi menurut komoditas (musiman atau tahunan), jangka waktu, jenis usaha dan kondisi sosial budaya masyarakat setempat. Perguliran dapat dilakukan baik dalam bentuk barang maupun uang sesuai kesepakatan kelompok. Perguliran dapat dilakukan antar anggota di dalam kelompok sehingga dapat menjangkau anggota yang lebih luas, perguliran antar kelompok, maupun melalui LKMA Amanah Mandiri Syariah.

Meningkatkan modal kelompok tani bisa juga dilakukan dengan meminjam modal dikelompok lebih meringankan dibanding meminjam di bank yang bunganya 2 kali lipat. Itulah manfaat Modal kelompok tani untuk kesejahteraan bagi kelompok tani itu sendiri. Salah satu kriteria kelompok tani yang mandiri adalah, kelompok tani memiliki modal kelompok. Modal kelompok mempunyai banyak manfaat baik bagi kelompok maupun anggota bahkan masyarakat sekitarnya. Modal Kelompok adalah semua aset baik berupa barang bergerak maupun yang tidak bergerak yang menjadi milik bersama dalam kelompok, dikelola secara bersama dan menjadi tanggung jawab bersama.

Ada beberapa manfaat jika petani bisa menghimpun modal kelompok, yaitu 1) Membentuk sikap hemat dan menghilangkan sikap boros, 2) Menyimpan dan mengembangkan modal, 3) Menyiapkan hari depan yang lebih baik, 4) Memperoleh jasa atau bunga, 5) Dapat membantu orang lain, 6) Meningkatkan permodalan / keperluan kelompok, 7) Dapat digunakan sebagai jaminan dan meningkatkan sisa hasil usaha kelompok, 8) Dapat di pinjam oleh anggota.

Sebelum melaksanakan kegiatan pemupukan modal, terlebih dahulu dilaksanakan rapat / pertemuan kelompok untuk membahas kegiatan pemupukan modal. Jika telah tercapai kesepakatan dalam kelompok, selanjutnya dituangkan dalam Berita Acara. Sebagai bukti bahwa telah terjadi kesepakatan dalam kelompok. Semua ketetapan yang ada dala kelompok semuanya adalah hasil kesepakatan, apapun bisa diterapkan jika telah disepakati bersama, khususnya dalam pengembangan modal kelompok. Dibawah ini bisa diambil sebagai 
langkah yang dapat ditempuh untuk menumbuhkan atau mengembangkan modal kelompok tani adalah

1. Jumputan/ jumpitan berupa :

a. Menetapkan iuran pokok anggota kelompok baik dalam bentuk barang atau uang, yang jenis dan jumlahnya tergantung kesepakatan anggota.

b. Menetapkan iuran rutin (per minggu / bulan / musim panen)

2. Iuran tenaga, pemanfaatan jasa kerja tenaga anggota dalam melaksanakan kegiatan yang menghasilkan pendapatan.

3. Simpanan / tabungan anggota dengan menyisihkan sebagian pendapatan anggota, yang besarnya tergantung kesepakatan.

4. Memberikan sewa asset, memanfaatkan aset kelompok seperti traktor, dros padi untuk disewa, hasil sewa masuk dalam kas kelompok

5. Usaha budidaya, melakukan usaha budidaya bersama kelompok (ternak, ikan, kebun dll).

Tabungan adalah bagian dari pengeluaran bukan sisa dari pengeluaran. Modal (tabungan) sangat penting dalam mengembangkan usaha yang ada atau memulai usaha baru. Kelompok harus menjamin anggota tidak meminjam ke pihak lain untuk menabung. Melalui kebiasaan menabung sehingga membuat anggota menjadi rajin datang dalam pertemuan kelompok dan ada kepercayaan serta kebersamaan.

Manfaat tanbungan bagi kelompok tani meningkatkan permodalan/keperluan kelompok, memenuhi kebutuhan pinjaman anggota, dapat digunakan sebagai jaminan dan meningkatkan sisa hasil usaha kelompok. Manfaat tabungan bagi anggota membentuk sikap hemat dan menghilangkan sikap boros, menyimpan dan mengembangkan modal, menyiapkan hari depan yang lebih baik, memperoleh jasa atau bunga dan pengaturan ekonomi rumah tangga.

\section{Kemajuan Kelompok Tani Setelah Adanya LKMA Amanah Mandiri Syariah}

Perkembangan petani merupakan harapan kelompok tani dan kemampuan pengurus dalam membuat perencanaan akan keberhasilan 
kelompok tani dalam kemajuan merupakan sesuatu yang di harapkan. Mengenai kemajuan kelompok tani setelah adanya LKMA Amanah Mandiri Syariah berdasarkan observasi penulis kehadiran LKMA "Amanah Mandiri" Syari'ah dapat menjadi solusi sumber pembiayaan bagi petani yang membutuhkan modal usaha dengan persyaratan yang dapat dengan mudah diakses oleh petani. Dengan adanya lembaga keuangan sebagai penyedia modal mendorong kelompok tani untuk aktif dalam melakukan kegiatan-kegiatan, kegiatan tersebut yaitu:

\section{Kegiatan Arisan}

Kegiatan ini dilakukan pada setiap hari Senin per musim. Arisan dilakukan pada malam hari mulai pukul 19.30 WIB setelah waktu sholat Isya'. Penanggung jawab kegiatan arisan ini adalah bendahara Kelompok Tani Mulya Jaya. Arisan dilaksanakan pada lokasi yang berbeda-beda dengan alasan agar semua anggota mendapat giliran tempat untuk kegiatan arisan. Lokasi yang berbedabeda disepakati pada ketentuan awal pada saat musyawarah bersama. Penentuan lokasi dilakukan pada setiap pembukaan arisan berdasarkan waktu yang paling lama mengikuti arisan.

Jenis arisan yang dilakukan adalah arisan berupa uang yang dihitung berdasarkan harga beras dan tanam modal, bila di contohkan ; A sebagai tempat untuk kegiatan arisan dan B membayar arisan/nandur 5, sedangkan harga beras 5.000, jadi 5x5.000 $=25.000$, dan seterusnya berlaku untuk semua orang dengan tergantung besaran yang di tanamkan modal/nandur. Selain arisan Kelompok Tani Mulya Jaya juga memberlakukan uang kas kelompok. Uang kas kelompok bukan dari setoran rutin dari anggota atupun pengurus. Namun uang khas kelompok diperoleh dari hasil arisan yang dibayarkan dengan penghitungan sebesar 20\% dari jumlah uang arisan yang diperoleh. uang khas kelompok digunakan untuk kegiatan kelompok. Uang khas juga dapat berasal dari pembayaran pembelian pupuk dari anggota ke kelompok tani sebesar Rp, 1000,-. Artinya jika ada anggota yang membeli pupuk akan dikenakan tambahan sebesar Rp 1.000,- untuk uang khas kelompok. Biasanya uang hasil dari arisan oleh anggota digunakan untuk tambahan guna pemenuhan kebutuhan sandang, pangan dan tabungan masa depan. 


\section{Kegiatan Diskusi}

Kegiatan diskusi ini dilakukan bersamaan dengan dilaksanakannya kegiatan yang lainnya. Kegiatan diskusi biasanya berada diakhir kegiatan setelah arisan dilaksanakan. Pembahasan yang sering menjadi pokok utama dalam diskusi Kelompok Tani Mulya Jaya adalah musim masa tanam, jenis varietas yang dipakai dan penanganan hama. Selayaknya kelompok yang menjadi wadah untuk tujuan bersama, masa tanam pun dilaksanakan secara bersamaan dengan jenis varietas yang sama sesuai dengan musyawarah anggota Kelompok Tani Mulya Jaya. Untuk pembahasan tentang penanganan hama dalam diskusi yang terjadi adalah bertukar informasi mengenai penggunaan obat atau penanganan hama secara teknis. Contoh penanganan hama yang sering terjadi sekarang ini adalah daun padi yang menguning, kering atau biasa petani menyebutnya penyakit teyeng. Penyakit ini tidak bisa dibasmi dengan cara manual karena hama yang menyerang daun padi tidak terlihat sehingga petani melakukan dengan menyemprot dengan obat Antracol, pada mula petani tidak tau cara menangani penyakit tersebut. Untuk pelaksanaannya dilapangan tetap dilaksanakan secara mandiri atau individu. Diskusi sangat berguna untuk setiap anggota kelompok. Manfaat yang didapat dengan adanya diskusi dapat sekaligus menjadi ajang musyawarah antar anggota kelompok.

Selain peningkatan dalam kegiatan diatas kelompok tani beserta anggotanya juga terlihat kemajuannya pada hasil tanamanya. Ini dapat dilihat pada kemajuan anggota kelompok tani tersebut.

\begin{tabular}{|l|l|c|c|c|}
\hline \multirow{2}{*}{ No } & \multirow{2}{*}{ Nama } & \multicolumn{2}{|c|}{ Rata-rata } & Persentase \\
\cline { 3 - 4 } & & Sebelum & Sesudah & \\
\hline 1 & Sukardi & $390 \mathrm{~kg}$ & $480 \mathrm{~kg}$ & 81,30 \\
\hline 2 & Suparji & $1.250 \mathrm{~kg}$ & $1.475 \mathrm{~kg}$ & 84,74 \\
\hline 3 & Saman & $450 \mathrm{~kg}$ & $545 \mathrm{~kg}$ & 82,64 \\
\hline 4 & Warigo & $1.230 \mathrm{~kg}$ & $1.538 \mathrm{~kg}$ & 80 \\
\hline 5 & Parimun & $1.260 \mathrm{~kg}$ & $1.613 \mathrm{~kg}$ & 78,12 \\
\hline 6 & Mustamar & $820 \mathrm{~kg}$ & $984 \mathrm{~kg}$ & 83,33 \\
\hline
\end{tabular}




\begin{tabular}{|l|l|r|r|r|}
\hline 7 & Giman & $390 \mathrm{~kg}$ & $472 \mathrm{~kg}$ & 82,64 \\
\hline 8 & Slamet & $1.250 \mathrm{~kg}$ & $1.450 \mathrm{~kg}$ & 86,21 \\
\hline 9 & Suparman & $1.300 \mathrm{~kg}$ & $1.560 \mathrm{~kg}$ & 83,33 \\
\hline
\end{tabular}

Tabel. Kemajuan kelompok tani.

Berdasarkan obervasi kepada petani bahwa rata-rata jumlah peningkatan hasil panen petani bertambah sebesar $80 \%$ setelah adanya LKMA "Amanah Mandiri" Syariah. Rata-rata petani merasakan dampak kemajuan setelah adanya LKMA “Amanah Mandiri” Syariah dimana mereka dapat memperoleh pinjaman modal usaha pertanian di LKMA “Amanah Mandiri” Syariah. Peningkatan hasil tani tersebut digambarkan dengan jumlah perolehan dalam bentuk kilogram karena setiap anggota kelompok tani hasil panen taninya tidak semua dijual, ada yang dipakai kebutuhan sehari-hari dan ada juga yang di jual musim depan dengan melihat kondisi harga tertinggi.

\section{Kesimpulan}

Berdasarkan hasil penelitian yang telah dilakukan mengenai Peran Lembaga Keuangan Mikro Agribisnis (LKMA) Amanah Mandiri Syari'ah Terhadap Kelompok Tani di Desa Sekarputih Kecamatan Bagor Kabupaten Nganjuk dapat disimpulkan bahwa:

1. Peran LKMA Amanah Mandiri terhadap kelompok tani telah dilakukan dalam memberikan pinjaman modal usaha kepada anggota LKMA untuk membeli kebutuhan pertanian seperti benih, pupuk dan lain-lain dengan menggunakan akad pembiayaan Musyarakah dimana anggota sebagai pemilik ladang pertanian sekaligus sebagai penggarap kemudian LKMA penyedia modal untuk memenuhi kebutuhanya. Dengan memberikan pembiayaan pihak LKMA tidak turun langsung untuk memenuhi kebutuhan pertanian melainkan melimpahkan wakil kepada anggota pembiayaan usaha pertanian. Dan tindakan yang dilakukan LKMA Amanah Mandiri Syariah ketika para anggota yang tidak sesuai penggunaan dana tersebut maka dilakukan peneguran, dikasih peringatan dan jika anggota masih tetap tidak sesuai 
dengan penggunaan dana pertanian tindakan yang dilakukan LKMA Amanah Mandiri Syariah tidak diberi pinjaman kembali untuk anggota yang tidak sesuai akad perjanjian awal.

2. Cara meningkatkan modal kelompok tani masih mengandalkan lembaga keuangan ataupun pihak lain dengan pengajuan pembiayaan untuk bisa disalurkan langsung kepada kelompok selanjutnya agar bisa digulirkan guna memperluas sasaran penerima manfaat. Dana penguatan modal digulirkan dengan pola perguliran yang bersifat spesifik lokal yang bervariasi menurut komoditas (musiman atau tahunan), jangka waktu, jenis usaha dan kondisi sosial budaya masyarakat setempat. Perguliran dapat dilakukan baik dalam bentuk barang maupun uang sesuai kesepakatan kelompok. Perguliran dapat dilakukan antar anggota di dalam kelompok sehingga dapat menjangkau anggota yang lebih luas.

3. Kemajuan kelompok tani setelah adanya LKMA Amanah Mandiri Syariah terlihat dapat mendorong kelompok tani untuk aktif dalam melakukan kegiatan-kegiatan positif seperti kegiatan arisan dan diskusi.

LKMA “Amanah Mandiri” Syari'ah dapat menjadi solusi sumber pembiayaan bagi petani yang membutuhkan modal usaha dengan persyaratan yang dapat dengan mudah diakses oleh petani. Dapat diketahui juga bahwa rata-rata jumlah peningkatan hasil panen petani bertambah rata-rata sebesar $80 \%$ setelah adanya LKMA "Amanah Mandiri" Syariah. Rata-rata petani merasakan dampak kemajuan setelah adanya LKMA “Amanah Mandiri” Syariah dimana mereka dapat memperoleh pinjaman modal usaha pertanian di LKMA "Amanah Mandiri" Syariah.

\section{Saran}

Dalam penelitian ini penulis memberikan saran kepada pihakpihak terkait. Hal ini bertujuan meningkatkan pemahaman khususnya dalam peran Berdasarkan hasil kesimpulan diatas maka dapat dikemukakan saran sebagai berikut:

1. Untuk Kelompok Tani dengan adanya pembiayaan modal usaha 
pertanian dari LKMA Amanah Mandiri Syariah kepada anggota kelompok tani sehingga bisa menjalankan kegiatan usaha yang lebih produktif dan dapat meningkatkan pendapatan usaha pertanian, maka gunakan sebaik-baik mungkin sesuai keperluan dan tingkatkan dalam perawatan lahan pertanian agar menghasilkan hasil panen yang lebih baik.

2. Agar LKMA Amanah Mandiri Syariah dapat berkelanjutan sebagai alternatif akses permodalan bagi petani dan pengusaha dibidang agribisnis di Desa Sekarputih, buat pengelola LKMA dan pengurus kelompok tani harus berupaya mengantisipasi peningkatan kredit macet yang terjadi karena sangat berpengaruh terhadap kelayakan keuangan. Antisipasi dapat dilakukan dengan memperbaiki aturan main pada kelembagaan yakni dengan memperbaiki pelaksanaan sreering agar lebih baik lagi, menambah incentive seperti memberikan reward kepada anggota terbaik, kemudian menambah enforcement pada LKMA Amanah Mandiri Syariah agar anggota dapat lebih terdorong untuk mengembalikan kredit. Untuk keberlanjutan LKMA Amanah Mandiri Syariah sumber daya manusia dapat ditambah lagi agar kerja seksi penggalangan dana, penagihan, pembiayaan, tidak perlu dirangkap oleh manajer dan kasir.

3. Diperlukan dukungan / dorongan dari Kepala Desa dalam meningkatkan kapasitas sumber daya manusia pada kelompok tani supaya bisa bersemangat untuk meningkatkan hasil pertaniannya. Dukungan bisa dalam bentuk pelatihan, penyediaan bibit unggul dll.

\section{Daftar Pustaka}

Rizki, Amelia (2016) Peranan Lembaga Keuangan Mikro Agribisnis (LKM-A) Dalam Usahatani Hortikultura pada Gapoktan Kompak Kelurahan Ganting Kecamatan Padang Panjang Timur. Universitas Andalas (http://scholar.unand.ac.id/19198/)

Daniel. Pengantar Ekonomi Pertanian. Bumi Aksara: Jakarta. 2007. 178. 
Departemen Pertanian, Pedoman Umum Pengembangan Usaha Agribisnis Pedesaan (PUAP): Jakarta. 2009, 27.

Kementrian, Pertanian. 2011. Pedoman Umum Pengembangan

Usaha Agribisnis Pedesaan (PUAP). Kementrian Pertanian. 46 hal.

Departemen Pertanian, 2009. Petunjuk Teknis Verifikasi Dokumen Pengembangan Usaha Agribisnis Pedesaan (PUAP). Jakarta. Departemen Pertanian. 36 hal.

Kementrian Pertanian. Petunjuk Teknis Pemeringkatan (rating) Gapoktan PUAP Menuju LKM-A. Kementrian Pertanian: Jakarta, 2010, 25. ( didalam thesis Rizki Amelia )

Budisantoso, Totok. 2005. Bank dan Lembaga Keuangan Lain. Edisi 1. Salemba Empat : Jakarta.

Rahardja, Prathama dan Mandala Manurung. 2004. Teori Ekonomi Mikro Suatu Pengantar. Fakultas Ekonomi Universitas Indonesia. Jakarta.

Soetanto Hadinoto.2005, Kunci Sukses Bisnis Kredit Mikro, Editor dan Penulis Apendiks: Djoko Retnadi, Jakarta : PT. Elex Media Komputindo.

Saragih, Bangaran DKK. 1998. Agribisnis Paradigma Baru Pembangunan Berbasis Pertanian. Bogor: Yayasan Mulia Persada. 86 hal.

Soekartawi, 1993. Prinsip Dasar : Agribisnis Teori dan Aplikasinya. PT. Raja Grafindo Persada, Jakarta.

Soekartawi, 2001. Pengantar Argoindustri, Edisi 1. Jakarta : Cetakan 2. PT Raja Grafindo Persada. 1-2,19-18 hal.

Sjarkowi, F. dan M. Sufri, 2004. Manajemen Agribisnis. Baldal Grafiti Press. Palembang.

Wibowo, S. 1994. Pedoman Mengelola Perusahaan Kecil. Jakarta: Swadaya.

https://febrianaanggraeni.wordpress.com/2013/08/23/artikel-tentangagribisnis/.

hasanmenakoo.blogspot.com, Pengertian Pengembangan Usaha Agribisnis Pedesaan. 8 Januari 2013 